\title{
Geo-economic Quandaries and Educational Exclusion in the Context of pastoralists The Case of Dasanech Children in Southern Omo, Ethiopia
}

\author{
Ziyn Engdasew Woldab (Ph.D) \\ Assistant professor, School of Educational science, \\ Adama University (P.O.Box-1888), Adama, Ethiopia \\ Email:engdasewziyn@yahoo.com \\ Melese Mekonnen (M.A) \\ Principal of Secondary School, \\ South Omo Zone of Southern Regional State
}

\section{Doi:10.5901/mjss.2013.v4n13p305}

\section{Abstract}

\begin{abstract}
The intent of this study was to examine the status of educational exclusion of pastoral Dasanech children in the primary schools of South Omo Zone, and identifying the major geo-economic impediments in their educational inclusion. To serve this purpose, descriptive survey research method was employed. The data were gathered from the sample of students, teachers, and educated personnel from Dasanech ethnic group, Parent-Teacher Association members, tribal chiefs and ethnically Dasanech school dropouts. Applying diversified sampling techniques drew these respondents. Apart from document analysis, information was solicited from the sample respondents through questionnaire, Interview and Focus Group Discussion. Mixed method procedures of Sequential Explanatory Strategy were used to analyze and interpret both the quantitative and qualitative data. The findings indicated that the status of educational exclusion of pastoral nomad Dasanechs' children in the primary school of the south Omo zone is low as compared to other ethnic groups. Whereas, the dropout rate of children from primary is high above the regional average. Based on the findings, geo-economic predicaments, like poverty, conflict, parents' illiteracy, nomadism, high demand of child labor and problem of health have been found to be the major geo-economic constraints. Formulation of specific policy and strategy for pastoral children education, school location mapping, flexible academic calendar, construction of semi-sedentary education centers and boarding schools, and introducing mobile tent schools, promoting participatory conflict management approaches were recommended.
\end{abstract}

Keywords: Nomads, pastoralists, participation, educational exclusion,

\section{Background of the Study}

Education is a basic condition for economic and social development, and primary education is its foundation (World Bank, 1998). Primary education in developing countries is well thought out to have great importance because of its wide range of benefits. These includes the shaping and strengthening of the child as an individual in relation to his or her fellow people, to nature, and to the world as an environment. It enables individuals to build a capacity for lifelong learning and to develop knowledge, skills and attitudes which will contribute to the general development of the community (Taylor, 1997).

In this regard, World Bank (1988:28) states "Education especially primary and lower secondary helps to trim down poverty by increasing the efficiency of the poor, and equipping people with the skills they need to participate fully in the economy and society". In view of this, it is widely accepted that all school-aged children should receive at least primary education, if human labour is to yield sustainability in the development of the country.

To put the pledge in to effect, the momentous international education conference held at Jomtien-Thailand in 1990, in which many regional representatives and international organizations were met and recommitted to Universalize Primary Education by the year 2000(Burckhardt, 2000). Moreover, the participants acknowledged that the then educational provision was seriously deficient and that must be made more relevant, quantitatively improved and made universally available. They eventually proclaimed "World Declaration on Education for All". To this end, all agreed to universalize basic primary education by the year 2000 at the global level, focusing mainly on ensuring access for all, even for the most inaccessible populations(Ibid). 
The Jomtien commitment was reaffirmed and extended at world Education Forum, held in April 2000 in Dakar, Senegal; in which many countries have recommitted themselves to the eight Millennium Development Goals (MDGs), aimed at eradicating extreme poverty and improving the welfare of their people by the year 2015. The second of the goals is; achieving Universal Primary Education (UPE) with the specific target of ensuring that by 2015 all children everywhere particularly girls, children in difficult circumstances, most vulnerable and disadvantaged children and those belonging to ethnic minorities have access to and complete primary education (Bruns and Mingat, 2003).

The international commitment to realise Education For All (WCEFA, 1990) in general and UPE in particular demands a meticulously close focus on those groups who, for a variety of reasons, have so far been debarred and marginalised from existing educational provision, among these marginalised groups, pastoral nomads are in the forefront (Dyer,C.,2001).

Pastoral nomads are people who live and derive most of their food source and income from raising domestic livestock, with no recognized place of residence, and move from place to place in search of pasture and water (Carhill, 2005). They are estimated around thirty six million in the world and the majority of them inhabited in seventeen African Countries-Mauritania, Algeria, Egypt, Sudan, Niger, Mali, Senegal, Ghana, Nigeria, Cameron, Uganda, Tanzania, Kenya, Somalia, Djibouti, Eritrea, and Ethiopia (Ezeomah, 1998). As minority groups, they represented 6 percent of African population categorized under disadvantaged and hard to reach population in terms of social service provision (Car hill, 2005).

In many countries of Africa, pastoral nomads live in parts of the country that hold potential promise for development. In most countries of Africa, they own about eighty to ninety percent of the large animals available in the country (Ezeomah, 1998). Pastoral nomad populations, though the poorest and most vulnerable, their animals, and the lands they control are potential resources for the nation (Doornbos and Markakis, 2000; Kratli, 2000).

However, most children of pastoral nomads in Africa are educationally excluded and still do not have access to formal and non-formal educational programmes, reaching them formal schooling has become a major challenge, and millions of nomadic children remain outside the education system. Their level of participation in every stage of formal education is far below the national average (Dyer \& Choksi, 1997, UNESCO, 2002).

Nomadic pastoralism as a way of life and provision of education for these people recently become an issue of government. This is because of that, the lack of educational credentials for nomadic pastoralists hamper their possibilities for democratic representation in national leadership (Nkinyangi, 1981). The situation also disallows them to forward any voice concerning the direction of their own lives and livelihoods (Heron, 1993). Hence, it is important to access education that facilitates social mobility and provides knowledge relevant to the communities' livelihood and traditions that give viable alternatives for nomadic communities in determining their ways of life (Dyer and Choksi, 1997).

In Ethiopia, the pastoral nomads' people are found nearly all low lands on the periphery of the country, covering about 65 percent of the total area of the nation. They are about 8 million in number and 13 percent of the country's population. Documentary analysis in Ethiopia holds that parts of the nation inhabited by population groups, whose main economic activity is livestock husbandry, are economically, politically and socially marginal. At the same time, however, it is believed that the area occupied by pastoralists are said to be rich, endowed in natural resources yet to be exploited and to be put at the service of the pastoral communities and the country as a whole (Ayalew, 1998, Yacob, 1995).

These pastoral areas are mostly lend themselves to large scale and mechanized agricultural development. For a long time in the past, there was no comprehensive and integrated policy ensuring sustainable livelihood for people in the pastoral areas of Ethiopia. In the same vein, their children educational participation was abysmally low, there were only little attempt to educate children of tribal and clan chieftains of the nomadic pastoral people. They were brought in to urban centers, and taught in boarding schools. However, they were few in number and its purpose was to prepare them to serve the then regimes. For that reason, most of the pastoral population had not benefited much from education system of the nation (Shileshi \& Kidane, 1997; Fekade, 1990).

Today, the Ethiopian government as a democratic polity and signatory of international conventions, committed to provide quality primary education for all school-aged children irrespective of race, religion, and geographic settings. This is also the major priority of the new Education and Training Policy of 1994. The Policy provided for a new structure, decentralized management, and localized languages as a medium of instruction. It was also in line with the objectives of the 1990 Jomtien Conference and the Dakar conference on Education for All as well as the Millennium Development Goals (MDG), which envisage universal access and completion of primary education by 2015. Over all, the policy directives could prove definitive in the efforts to achieve UPE and EFA.

The evaluation reports of the Education Sector Development Programs(ESDP-IV) in Ethiopia indicates tremendous growth trends of educational participation of school aged children in primary education in many of the 
regions of the country. With respect to the nomadic pastoral groups, however, the education provision leaves much to be desired (MOE, 2012).

These circumstances plainly confirms that providing education to nomadic pastoralists is one of the most challenging and urgent issues currently facing educational policy makers, practitioners and other actors with in the field in the nation. Hence, it is very difficult to achieve the goal of equality of educational opportunity, Education for All (EFA), Universal Primary education (UPE) and Millennium Development Goal (MDG) in general, so long as these groups are forgotten educationally.

If Education for All (EFA) and the Millennium Development Goal (MDG) are to be achieved, obstructive factors should be analysed and more diversified and integrated alternative intervention strategies need to be designed to increase educational opportunities for nomadic pastoral communities in Ethiopia. Attaining the two education goals of MDGs-Universal Primary Education (UPE) and eliminating gender disparities are dependent not just on mass enrolment drives, but also on targeting and reaching those smaller percentages of educationally excluded groups who currently unable to access the education system, like children of nomadic pastoralists. The primary school coverage of in the pastoralist areas of South Omo Zone is 34 percent. The rest do not have access to any form of education service (SNNPR, 2012).Research findings in different pastoral areas of the country and other African countries reveals that the predicament for educational participation found to be not only socio-culture but also geo-economics activities of the society.

Hence, in this study an attempt is made to investigate major geo-economic quandaries in the educational participation of nomadic pastoral Dasanech children in primary education. In doing so, the following guiding questions are designed.

- What is the status of educational exclusion of nomadic pastoralist Dasanech children in primary education ?

- What geo-economic quandaries hinder their educational participation?

- To what extent geo-economic predicaments contribute to their educational exclusion in education?

- What strategies should be implemented to minimise the exclusion and promote their participation in primary education?

\section{Objectives of the Study}

The objectives of this study are:

- To assess the present status of exclusion and involvement of nomadic pastoral Dasanech children in the primary education.

- To examine the major geo-economic predicaments which contribute for social exclusion of Dasanech children in primary education.

- To investigate the extent of influence of geo-economic quandaries for their educational exclusion of pastoral Dasanech children in primary education.

- To review and analyse the intervention strategies to minimise geo-economic constraints

\section{Scope of the Study}

This study is limited itself to investigate the geo-economic influence on educational exclusion and inclusion of nomadic pastoralist Dasanech children in primary education in south Omo zone of Ethiopia and investigating alternative intervention strategies to minimise educational exclusion and promoting their educational enrolment and attendance. Even though the nation has 29 pastoralist ethnic groups; this study is restricted only to Dasanech pastoralist in Southern Omo of Ethiopia. It is also obvious that the causes for exclusion in education in developing countries, are many and diverse, this study, however, has limited itself mainly on the major geo-economic situation of the Dasanech pastoralists children and its impact on their enrolment and attendance in primary education .

\section{Litrature Review}

\subsection{Nomadism and Pastoralism: The Conceptual Frame Work}

Scholars argue that, due to pastoralists' difference in geographical distribution, composition of herds, distance, seasonality of their migration, character of dwelling and degree of sedentary, there is no universally accepted definition 
for nomads, nomadism, pastoralism, and pastoralists. The definition that was agreed up on by many scholars is provided below.

According to Markakis, pastoralism is a mode of production that depends on natural forage in the arid region, which requires periodic movement in search of pasture and water with their animals. It is a life style based upon maintenance and total dependence on herds of animals, which depend mainly on natural vegetation for their food (Markakis, 1993).

In Ethiopian context, Pastoralism is defined as a way of life and geo- economic activity, which is based mainly on livestock production by using available scarce resources and livestock depend on natural forage, so the people who undertake such life style are pastoralists. It is a labor-intensive adaptation where people maintain on livestock resources (Getachew, 2001).

As defined by Socio- anthropologists, Pastoralists are part of the society, who primarily live and derive most of their food source and income from raising domestic livestock, which differentiate them from agro-pastoralists, who promote opportunistic crop farming integrated with the livestock husbandry practice (Bruke, 2002). In short, pastoralists are people who are primarily raising and depending on livestock and their products as their source of food and income (Dawit, 2000).

According to Tahir, nomads are an ethnographic group moved from one place to another, having no fixed home. Their movement was necessitated by culture and economic demands such as cattle rearing, hunting, gathering, fishing, and doing craft work. They lived in harsh climatic conditions usually without the necessities of life (Tahir, 2006).

Broadly speaking, they are ethnic or socio-economic groups who constantly travel and migrate in large or small groups in search of means of livelihood with in a community, country, or international boundaries. These groups are differing from the settled or sedentary population, living in villages, towns and cities, and tied to fixed location by agriculture, employment, housing and social and cultural factors (Carr-Hill, 2005).

Similarly, UNESCO defined nomadism as any type of existence characterized by absence of a fixed domicile. It is a way of life, or economic activity that has evolved in areas that can hardly be used otherwise (UNESCO, 2002). According to Mugerwa $(1992 ; 13)$ "nomadism is a highly mobile production system that doesn't undertake any cultivation and doesn't have any base on the rangelands." He has been categorized nomads in Africa in to three major groups, namely,

1. Migrant fisherman, who are predominantly found along the riverie areas, lakeshores and the coasts of Atlantic and Indian oceans in Africa.

2. The hunters and food gatherers who are predominantly found in the rift valley around Lake Nyasa in the northern parts of Tanzania, Namibia and the rain forest areas of central Africa.

3. Pastoralists, which include the Fulbe in West Africa, the shuwa Arabs in Nigeria and

Cameroon, the Massai, the Turkena and the Rendelle in Kenya, Tanzania, the Karamajon in uganda, the Somalia nomads, the Tuaregs in Libya, Nigeria and Chad, Dasanech, Afar, Somali and Borena,Dasanech,Hammer, Kereyu etc... in Ethiopia.

In general, when we say pastoral nomads or nomadic pastoralists, it means part of the society in which the husbandry of grazing animals is viewed as an ideal way of making a living and regular movement of all or part of the society is considered a normal or natural part of life. They settle in geographically remote parts of the countries in which their economic way of life rely on and affect their degree of benefits in social service provisions like education.

\subsection{Geo-economic Predicament and Social Exclusion in Pastoralist Education}

The influence of geo-economic conditions on educational exclusion in primary school is perhaps the most constant and consistent findings of socio-educational research worldwide (Izquerdo and Levin, 1989 in Noriega, 1996). Together with the socio-cultural constraints, sending children to school entails direct and opportunity costs, that is prohibitive to poor and rural parents. Policy measures and intervention strategies are shown to have had little impact on increasing access and participation of pastoralist communities in primary education; for they have usually been introduced without serious consideration of the prevailing socio-economic conditions (Sifana, 2005). The following sections deal with such factors for educational exclusion and to withdraw children from school.

Poverty: Poverty and its consequence of malnutrition are common in the pastoral areas of Africa. As Kratli notes, due to the increasing degradation, conversion and reduction of pastureland, the problem of food shortage is an acute problem in the pastoral societies. In the period of severe drought, inadequate diets may lead to a total breakdown in household's ability to feed themselves and their children (Kratli, 2000). In this perspective, it is clear that, parents with 
poor economic status may have difficulty in providing their children with educational materials and buying uniforms (Steven, 1993).

Parents Illiteracy: as one socio economic constraint, educational level of parents is an important determinant of educational exclusion. As Magland (1994) portrays education of parents affects the children's school enrolment and year of schooling significantly. The research findings by Hyde (1989) indicate that educated parents are more likely to send their children to school and keep them longer in schools. On the contrary, illiterate parents are highly associated with high children dropout rate (Rumberger, 1987). When we see its effect with nomadic areas, it is obvious that the nomadic groups of the world are the most severely disadvantaged groups in the acquisition of education. In fact, the rate of illiteracy among nomadic pastoralists ranges from 80-100 percent in many African countries (Ezeomah, 1995). For instance, the kwaahala nomads of the Sudan are illiterate, thus they include their children as soon as possible in the division of labour, which is found to be the primary constraint for lack of attendance in schools (Ronde, 1980).

Pastoral Economic Life: In most African countries, nomadic people are the most educationally excluded and neglected group of the society in the provision of education. Thus, enrolment and participation of nomadic children are low as compared to the children of other parents who lead a settled life. This is because of the fact that these people have pastoral economic life with no permanent domicile and it is difficult to build schools, near to them as they are constantly on the move. Even those few children who could enrol in the primary education are forced to withdraw, since most of the schools are found very far from their roaming villages. The problem of distance is worse especially for girls (UNESCO, 1995).

Child Labour: Child labour is very essential to the livelihood of some households. Particularly in the low land pastoral nomads areas, because of the labour intensive nature of the herding of cattle, nomadic pastoralists' children are significant contributors to the household income through their labour. Children involvement in households work is a common phenomenon across all levels of livelihood security in nomadic societies, in fact better of household with large herds are likely to have a higher labour demand. Thus, parents are reluctant to send their children to school (Kratli, 2000).

Health Problem: Health problems of children especially in poor and marginalized areas of African countries are very serious. They often suffer from fever, diarrhoea, recurring headaches, stomach pains, etc. For instance, a study made in Uganda shows, of the grade seven children who were asked if they ever suffered from specific health problems, 78 percent claimed to have had malaria, 12 percent had trachoma, and 5 percent had seen tapeworm and 3 percent had been treated for malnutrition (Bishop, 1994). In Paraguay, 10 percent of the contacted parents stated their children had dropped out of school because of ill health (UNICEF, 2000).

Conflicts: Pastoralist areas are prone to ethnic/clan/tribal conflicts and clashes over land and land resources, such as water, pasture, and salt. It may arise also to gain social status by possessing large herds of animals. This conflict leads to significant loss of properties and increased level of poverty and mobility (UNESCO, 2002).

For instance, in Nigeria, land use has been the main source of conflict between land cultivators and the nomadic pastoralists. Even though there were mutual beneficial relations between the two groups, through time conflicts arise because of increase in population and need to produce more food crops by cultivators. Consequently, pastoral nomads are rejected from the land they occupy for longer times. This ejection accelerated their migration and dispersion. Thus, children spend most of their time walking long distances to feed their animals and have little time for other activities (Ezeomah, 1995).

Another shortcoming that challenges to universalize primary education in developing countries has demographic in nature. This demographic aspect refers to rapid population increase. As World Bank indicated, the primary school age population in developing countries will increase by about 89 million children between 1990 and 2000, but by only 22 million between 2000, and 2012 (WorldBank,2012).

\section{Research Methodology}

\subsection{Research Design}

This study was mainly quantitative and substantiated with qualitative data from focus group discussion with PTA (Parent Teachers Association) members, and interview with dropouts, educated Dasanech and Dasanech tribal chiefs. Hence, the study design is mixed method design of sequential explanatory. 


\subsection{Instruments}

The quantitative data were gathered through questionnaire. The researcher collected and design questions from research reviews on the provision of education for Nomadic pastoralists (Kratli, 2001). The content validity of the questionnaire is measured by the three point scale measurement procedures developed by C.H.Lawshe (1975). The reliability of the questionnaire was also piloted and yielded a coefficient of Crobbach alpha 0.843 .

A semi-structured Interview guide was also employed to obtain additional information from Dasanech tribal chiefs, educated Dasanechs and ethnically Dasanech school dropouts. This particular data collection method was used and followed the pastoralists' social rule of dialogue and interaction, and respected their integrity and confidence. As Silverman (1994) observed, the semi-structured interviews offer a rich source of data, which provides access to how the respondents account for both their troubles and good fortunes.

Focus Group Discussion (FGD) guides were used to triangulate and enrich the information by gathering data from PTA (Parent Teacher Association) members. A variety of documentary sources was also reviewed in order to secure relevant data for analysis and to substantiate the validity of the primary data through triangulation. The reliability of the data in this study was also confirmed as a result of convergence of the responses arising from the triangulation of the different tools of data collection combined with the purposeful sampling.

\section{Sample and Sampling}

Southern nation and nationalities regional state in Ethiopia comprised of many pastoralist groups of people in which most of them inhabited in southern Omo zone. Among the pastoralist groups, the researcher randomly selects Dasanech pastoralists, in which they live in one district.

With respect to primary schools, two of them were taken out of five primary schools in the sampled Dasanech district using simple random sampling. Regarding student respondents, 80 were randomly taken from the total population of grade $7 \& 8$ students. This has also comprised of 38.5 percent of the total native Dasanech students in the sampled schools. Moreover, 32 teachers were taken randomly from the two sampled primary schools.

Moreover, two Dasanech tribal elders, educated Dasanech, who are completing college education and employed in the regional offices, and dropout students from the pastoralist Dasanech backgrounds, were purposefully selected and involved in the interview session. Moreover, all Parent Teacher Association (PTA) members working in the primary schools were purposefully involved in Focus Group Discussions (FGD). As Patton states "the logic and power of purposeful sampling is lies in selecting information rich cases for depth study. The purposeful sampling enables the researcher to identify information rich sources among the pastoral communities and those working with pastoral communities that are knowledgeable and with vast experiences on nomadic pastoralism (Patton, 1990).

\section{Methods of Data Analysis}

To analyze the quantitative data various statistical techniques were employed as deemed appropriate in view of the objectives of the study. Statistical tools like , mean, SD T-test were used and analyzed using statistical package for social sciences (SPSS) version -17 for windows. For each factor, the significance of the F-test result is indicated by the symbol $\left.{ }^{*}\right)$. The qualitative data were gathered through interview, FGD, and documentary analysis. The data were analyzed qualitatively using reflective interpretations, which cross validate with the quantitatively analyzed data results. Thus, mixed methods of Sequential Explanatory Strategy were used to analyze and interpret both the quantitative and qualitative data, to arrive at some findings, crystallize in to conclusions and recommendations.

\section{Results}

\subsection{The status of Participation of Nomadic Pastoral Dasanech Children in Primary Education}

As per the statistical annual educational abstract of the southern nation, NER at the primary level in the region level oscillated up and down in the last five years period 2006/7-2011/12. In2011/12, the net enrollment rate became 92.3\% which is 5 percentage points higher compared to the status of 2010/2011(SNNPR, 2012).

Whereas, the zonal comparison indicated that Guraghe Zone, Hawassa City Administration and Silite Zone seem to have better position in relation to NER of primary education as is guessed from their NER of $105.9 \%, 104 \%$ and 
101.3\% respectively. On the other hand South Omo, Segen and Gedeo Zones had low NER of $68.5 \%, 72.5 \%$ and $77.7 \%$ in order during the same year. Among these zones South Omo zone the zone which is predominantly inhabited by pastoralist, among others are Dasanech group. South Omo zone is the least among the other zones and special districts in the region. The primary school coverage of South Omo Zone is 34 percent. The rest do not have access to any form of education service (SNNPR, 2012).

The situation is particularly problematic for the pastoral communities of Kuraz, Hamer, Dasanech and BenaTsemay woredas, with $6 \%, 7 \%$ and 14\%primary education coverage, respectively. The dropout rate is 14.4 percent which is above average of the national. This zone should, therefore, work at their best pace to make adjustment for the poor performance they experienced in capturing students at the right age. Overall, the educational participation of the pastoralist woredas is much lower than the average enrollment rate in southern nation and nationality regional state.

It has an implication that there is still educational exclusion in which provision of proper educational opportunities to the inaccessible nomadic pastoral ethnic groups, who are deprived of educational opportunities, is a big challenge of a nation, because of different impeding factors.

In general, in the struggle towards achieving education for all, a multitude of factors has resulted in poor participation, high dropout rates and absence of equity at primary education level.Some of the specific geo-economic factors for social exclusion in pastoralist education will be treated under different topics in the ensuing sections.

Table 1: The Nomadic way of life of Dasenech (mobility \& sparse settlement)

\begin{tabular}{c|c|c|c|c|c|c}
\hline \multirow{2}{*}{ Item } & \multirow{2}{*}{ Subject } & \multirow{2}{*}{ No. } & \multirow{2}{*}{ Mean } & \multirow{2}{*}{ SD } & \multicolumn{2}{|c}{ Equality of Variance } \\
& & & & & F-Value & Sig. \\
\hline \multirow{2}{*}{ The Nomadic way of life of Dasenech } & Student & 30 & 3.6533 & 3.6533 & \multirow{2}{*}{32.040} & \multirow{2}{*}{.000} \\
\cline { 2 - 4 } & Teachers & 75 & 4.6333 & .61495 & & \\
\hline
\end{tabular}

It is also well known that the movement of pastoral people from one place to another for economic purposes is the cause for the discontinuation of children's in formal schooling. Similarly, in this study, the mean computational result of students $(\bar{x}=3.65)$,teachers $(\bar{x}=4.63)$ shows that all group of respondents rated the item above average, moreover, the teachers, exceptionally rated the nomad pastoral way of life as a major influential reason for their social exclusion and low educational participation of pastoral Dasanech children.

The interviewees and FGD participants also confirmed this reality. The level of participation of nomadic pastoral Dasanech children in education is constrained by their mobility. Dasanech parents' constant mobility leads to low enrolment and high dropout rates of their children in formal schooling. Most of the time, a large number of Dasanech households (six to sixty), move together, and form a bigger settlement camp of a specific tribal/clan groups). They also arrange their mobility to takes place at a clan level.

The most frequent reason for their mobility at the clan level is severe scarcity of water and pasture. Another reason for their mobility is to avoid harmful insects like beating flies and mosquitoes. Their movement is seasonal mostly from dry season grazing lands to wet season pasturelands. Their mobility is not aimless or random, but with definite objectives, at certain times of the year and to particular places. It is well planned in pastoral context. This mobility is a strategic technique of pastoral production that changes according to ecological conditions.

For Dasanech pastoralists, searching of water is not the only reason for this mobility. These pastoralists leave areas even when there is permanent water because of their animals need a variety of forage and vegetation. In general, they strongly assert, "The only hope of survival in their semi arid land is movement". Hence, the increase of their mobility implies, low enrolment and high drop out of children from schools. This is because not only of the labor-intensive nature of children in the labor division of pastoral economic activity, but also in the subsistence livelihood of pastoral economy, children will not left behind to attend schools when their parents move with their cattle.

On the contrary, tribal chiefs and some Dasanech informants have a different opinion on the hindering role of mobility on the educational provision to their children and the society. They complain not on their mobile lifestyle, but on the government's reluctance to give educational opportunity that suits to their way of life.

Thus, according to these respondents, their mobile way of life should be partially considered as a case for their exclusion to the educational provision of the society. However, they admit that nomadic way of life is a problem for educational delivery if it is compared to sedentary people, but not impossible if the pastoralist people are considered as a part of the society and nomadic way of life is as a rational way of life. They claim that the approach to the educational provision should suit to the rational nomadic way of life of the pastoral Dasanech society. 
Table 2: Child labour

\begin{tabular}{c|c|c|c|c|c|c}
\hline \multirow{2}{*}{ Item } & \multirow{2}{*}{ Subject } & \multirow{2}{*}{ No. } & \multirow{2}{*}{ Mean } & \multirow{2}{*}{ SD } & \multicolumn{2}{|c}{ Equality of Variance } \\
\cline { 6 - 8 } & & & & & F-Value & Sig. \\
\hline \multirow{2}{*}{ The Centrality of child labour } & Student & 75 & 3.32 & 1.54360 & 12.424 & .001 \\
\cline { 6 - 8 } & Teachers & 30 & 4.33 & .61495 & & \\
\hline
\end{tabular}

With regard to the centrality of child labour, in the pastoral economic activity, most respondents rated it above average, in which they indicate that the high demand of child labour in pastoral economic activity highly affects Dasanech children educational participation. Moreover, the mean score differences of the study groups for this variable were not statistically significant at an alpha level $(<0.05)$. Hence, no one group of respondents has rated below average and all the interviewees agreed that the high demand of child labour in the division of labour of pastoral economic activities in which livestock herding is the main responsibility of children.

According to dropout children, one of the major reasons for their dropout of schooling was that parents were dependent on their children for herding animals and for undertaking other household tasks. These tasks were very important for the survival of a fragile community, as their life style is labor intensive. Thus, Dasanech parents perceived that they could benefit better from the immediate achievement of the child in livestock raring than schooling.

Table 3: Drought and Poverty

\begin{tabular}{c|c|c|c|c|c|c}
\hline \multirow{2}{*}{ Item } & \multirow{2}{*}{ Subject } & \multirow{2}{*}{ No. } & \multirow{2}{*}{ Mean } & \multirow{2}{*}{ SD } & \multicolumn{2}{c}{ Equality of Variance } \\
\cline { 6 - 8 } & & & & & F-Value & Sig. \\
\hline \multirow{2}{*}{ Poverty because of frequent drought } & Student & 75 & 3.1867 & 1.32230 & \multirow{2}{*}{683} & \multirow{2}{*}{$.410^{\star}$} \\
\cline { 2 - 4 } & Teachers & 30 & 3.3667 & 1.42595 & .683 &
\end{tabular}

* Significant at alpha level $(<0.05)$

Concerning poverty as a factor to educational exclusion, the mean computed results shows, students, $(\bar{x}=3.18)$, teachers $(\bar{x}=3.36)$ rated above the median indicating that poverty brought about by drought constrains the educational participation of pastoral Dasanech children. The multiple comparison result for this item also shows a statistically significant mean score differences at an alpha level $(<0.05)$ between student, teachers respondents. This tells us that teachers and students' rating high above average and considered consecutive drought as a major geo-economic challenge.

The respondents of the interview and PTA (Parent Teacher Association) members confirmed that cyclic drought results in decline of real income and reduction of output (milk and meat) and livestock prices because of reduction in marketable livestock quality. It also aggravates conflicts and poverty. Consequently, there is a mass dropout from school due to drought and an acute shortage of water. In extreme cases, the tribe migrated, leaving schools empty.

Table 4: Tribal conflict

\begin{tabular}{c|c|c|c|c|c|c}
\hline \multirow{2}{*}{ Item } & \multirow{2}{*}{ Subject } & \multirow{2}{*}{ No. } & \multirow{2}{*}{ Mean } & \multirow{2}{*}{ SD } & \multicolumn{2}{|c}{ Equality of Variance } \\
\cline { 5 - 7 } & & & & & F-Value & Sig. \\
\hline \multirow{2}{*}{ Tribal conflict } & Student & 75 & 3.3867 & 1.31410 & \multirow{2}{*}{10.686} & \multirow{2}{*}{.001} \\
\cline { 2 - 4 } & Teachers & 30 & 4.4333 & .81720 & & \\
\hline
\end{tabular}

Pertaining to conflict, the mean computational result of students $(\bar{x}=3.38)$,teachers $(\bar{x}=4.43)$ clearly shows that it has been rated above average by all group of respondents to indicate that it has a great influence on the educational participation of pastoral Dasanech children.

In this regard, the research participants explain that inter-tribal and intra-tribal conflicts frequently arise due to increased competition over grazing and farming lands and water. This is intensified by the increase of human and livestock population and the decrease of the amount of drinking water, pastureland due to recurrent drought.

Due to heavy dependence on their cattle and herds for their livelihood, nomadic pastoral Dasanech inhabiting the fluid plain of different rivers and dry land plains of the Dasanech area have frequently clashed with Ari, Hammer pastoralists over the best grazing lands and water points.

Conflict also interrupts and affects the market routes and existing trade relationships as the groups stopped visiting one another, local markets for fear of retaliatory attacks on the market routes. It also discourages grain suppliers who come from highlands and aggravates poverty and problems of cash income. Conflict also breaks out between Dasanech 
clans. This type of conflict is observed whenever a clan moves into a territory, which traditionally belongs to another clan. . When a boy reaches adolescence, he obtains the gun, usually given as a gift by his father for herding and warring, which are interwoven with their lives rather than sending to schools.

Table 5: Population growth of the society

\begin{tabular}{c|c|c|c|c|c|c}
\hline \multirow{2}{*}{ Item } & \multirow{2}{*}{ Subject } & \multirow{2}{*}{ No. } & \multirow{2}{*}{ Mean } & \multirow{2}{*}{ SD } & \multicolumn{2}{|c}{ Equality of Variance } \\
\cline { 6 - 7 } & & & & & F-Value & Sig. \\
\hline \multirow{2}{*}{ Fast population growth of the society } & Student & 75 & 3.2933 & 1.36336 & \multirow{2}{*}{2.744} & \multirow{2}{*}{.101} \\
\cline { 2 - 4 } & Teachers & 30 & 3.9667 & 1.18855 & \\
\hline
\end{tabular}

One of the challenges to universalise primary education in developing countries is a rapid population increase (World Bank, 1995). However, in the literature, it is shown that the fertility rates in African pastoral societies were generally lower than in sedentary societies, who have based their life on agriculture. These low population growth rates were primarily believed to have been maintained by a combination of comparatively high mortality rates and low fertility rates (Helland, 2001).

In this respect, respondents were asked to rate the degree of influence of population growth in the educational participation of nomadic pastoral Dasanech children in primary education. Thus, the mean computational results, students $(\bar{x}=3.29)$, teachers $(\bar{x}=3.96)$ indicate that all the respondents rated the item above average to reveal its significant influential role in the educational participation of nomadic pastoral Dasanech children.

Table 6: The illiteracy of the society

\begin{tabular}{c|c|c|c|c|c|c}
\hline \multirow{2}{*}{ Item } & \multirow{2}{*}{ Subject } & \multirow{2}{*}{ No. } & \multirow{2}{*}{ Mean } & \multirow{2}{*}{ SD } & \multicolumn{2}{|c}{ Equality of Variance } \\
& & & & & F-Value & Sig. \\
\hline \multirow{2}{*}{ The illiteracy of the society } & Student & 75 & 4.0800 & 1.29197 & \multirow{2}{*}{31.034} & .000 \\
\cline { 2 - 3 } & Teachers & 30 & 4.8000 & .48423 & & \\
\hline
\end{tabular}

With regard to the impact of illiteracy, the mean computational result of students $(\bar{x}=4.08)$, teachers $(\bar{x}=4.8)$ shows that all the group of respondents rated above average to indicate its significant influence in the educational inclusion of nomadic pastoral Dasanech children.

On the other hand, the result of T- test indicates that there were statistically significant differences between the mean scores of the study groups' in terms of their perception about the influence of parents' illiteracy on Dasanech children's educational participation. Employing, Levene's Test for Equality of Variances, it was found out that there are significant mean variations between students and teacher respondents.

It should be noted that, although the result of the analysis of, Levene's Test for Equality of Variances, revealed a significant variation, it would be safe to presume that illiteracy of Dasanech parents has significantly contributed for their educational exclusion of pastoral nomad Dasanech children in primary education.

Table 7: Poor health condition of the pastoralist society

\begin{tabular}{c|c|c|c|c|c|c}
\hline \multirow{2}{*}{ Item } & \multirow{2}{*}{ Subject } & \multirow{2}{*}{ No. } & \multirow{2}{*}{ Mean } & \multirow{2}{*}{ SD } & \multicolumn{2}{|c}{ Equality of Variance } \\
\cline { 5 - 7 } & & & & & F-Value & Sig. \\
\hline \multirow{2}{*}{ Poor health condition of the pastoralist society } & Student & 75 & 3.3733 & 1.39277 & \multirow{2}{*}{.909} & \multirow{2}{*}{.343} \\
\cline { 5 - 5 } & Teachers & 30 & 2.6667 & 1.29544 & &
\end{tabular}

In the case of health problem as a factor to the educational participation of Dasanech children, the mean computational result further shows that students $(\overline{\mathrm{x}}=3.37)$, teachers $(\overline{\mathrm{x}}=2.66)$ rated above average by all groups of respondents, which implies that it has a hindering role in the educational participation of pastoral Dasanech children.

The mean computational result further shows that there is statistically mean score difference at alpha level $(<0.05)$ between respondents in which students rated health problem higher than teachers to consider it as one hindrance. It is truism that, to learn properly an individual should be healthy. Nevertheless, a number of school children might be subject to premature school leaving due to personal and parental health problems.

As to interviewees, the pastoral Dasanech areas, the absence of health facilities and veterinary services in the 
pastoral areas of Dasanech worsened health problems. From this, it could be said that health problem is an obstructing factor in the educational inclusion of pastoral Dasanech children.

In general, from the six geo-economic barriers supposed to hinder pastoral nomad Dasanech children's participation in primary education, groups of respondents ranked in accordance with their degree of influence. As to their rank order, the first three major geo-economic challenges are parents' illiteracy, nomadic pastoral way of life and high demand of child labour in the pastoral economic activities.

\section{Summary and Conclusion}

- The study revealed that the both the children Gross Enrollment and Net Enrolment Ratio of pastoral South Omo Zone have the lowest as compared to other zones of the region. Among the pastoralist communities in the zone, the educational involvement of Dasanech children in the primary education is very minimal, whereas the dropout rate is high above the national and regional average.

- The findings of the present study revealed that cyclic drought in Dasanech are resulted in the loss of human lives and animals, consequently in decline of households' income and reduction of output and livestock prices, because of reduction in marketable livestock quality and lack of nearby appropriate market centers, which resulted in a mass dropout children from schools.

- The study disclosed that the high demand of child labour in the division of labour of pastoral Dasanech economic activities in which livestock herding is the main responsibility of children. Thus, the high demand of child labour is the major reason for their dropout of schooling, due to the reason that parents were dependent on their children for herding animals.

- The study showed that, high illiteracy level of pastoral Dasanech, which has influenced negatively on Dasanech pastoral communities by keeping them ignorant, poor and marginalized.

- The study also found that inter-tribal and intra-tribal conflicts frequently arise in the pastoralist community of South Omo Zone, due to increased competition over grazing and farming lands and water. This is aggravated by the increase of human and livestock population and the decrease of the amount of drinking water, pastureland due to recurrent drought .In such unstable circumstances, pastoralist Dasanech parents feel insecure to send their children to schools.

- The finding of this study disclosed that the pastoral Dasanech areas in addition to their fragile ecology and harsh environment, they are susceptible to malaria; water born and other communicable diseases. This implies that the Dasanech society and their children have a high incidence of health problems associated with malnutrition. These health problems are worsened by the absence of health facilities which lead pastoral Dasanech students to discontinue their schooling.

To sum up, Dasanech pastoralists' constant migration in search of water and pasture for their livestock, the critical role or high demand of child labour in the pastoralist geo-economic activity, high poverty situation because of frequent drought, and Pastoral Dasanech parents' illiteracy are the four top ranked geo- economic impediments, which hamper the educational inclusion of nomadic pastoral Dasanech children in primary education.

In general geo-economics activities of the Dasanech pastoralist are recognised as the major reason for educational exclusion of their children in primary education. In agreement with this finding, Akaranga (1995) posited that one of the major constraints that face the Kenyan government in providing education for nomadic pastoralists children is geo-economic constraints inherent to the pastoralist society. A similar study by Bishop reveals that the reason for dropout lays in the geo-economic conditions of the people concerned, i.e. inability to pay school fees, withdrawal of older children to herd cattle, sickness due to malnutrition and lack of medical care. Girls also, withdraw from school to act, as child nurses to the younger children, while mothers are engaged in the family duties of pastoral economic activity, which hinder their educational participation (Bishop, 1994).

It has an implication that the provision of proper educational opportunities to the in accessible pastoral ethnic groups, who are deprived of educational opportunities, is a big challenge of a nation. Hence, it can be concluded that this becomes a challenge to the country's goal of attaining universal primary education by 2015. It also implies that mere expansion of formal education provision based on a model of what works in urban and agricultural situation, is not suffice to ensure that Education for All and to reach pastoralist Dasanech children. Thus, Educational interventions for pastoralist Dasanech communities require a proper understanding of the geo-economic situations, which directly affects pastoralist communities. 


\section{Recommendations}

Depending on the research findings obtained from the study, the following intervention strategies and approaches are suggested to remedy the geo-economic constraints and improve the educational inclusion of pastoral nomad Dasanech children in primary education of south Omo zone of southern Regional state.

> South Omo Zoneal state education department should have to formulate clear strategies specific to their pastoral nomads' societal needs, geo-economic, and environmental settings to provide education for the majority of pastoral nomad Dasanech children.

$>$ South Omo Zonal education department with district education offices need to construct more semi-sedentary and cost effective non-formal mobile alternative basic education centers to give educational opportunities for Dasanech children in accordance with their temporal settlement camps, which has an advantage of giving education for children in their own culture and environment. The traditional clan structure should have to be the base for introducing; managing, monitoring and evaluation of the mobile educational programs Moreover, in order to minimize the risk of erecting schools without students, school mapping has paramount importance.

$>$ The regional education bureau in collaboration with the zonal and woreda education offices should construct low cost primary boarding schools for Dasanech children. It is also recommendable to the regional government and education offices to promote school feeding programmes with NGOs like WFP (World Food Programme) to provide food to primary school students in the Dasanech pastoral areas, with the intention to encourage nomadic pastoral Dasanech children to attend schools as well as to improve their nutrition. It is further recommended that the federal and regional government should have to establish appropriate market centers in the pastoralist Dasanech areas.

$>$ The regional education bureau should be advised to design a more flexible day and annual education calendar in consultation with pastoralist tribal and clan leaders. The education calendar should take in to account the seasonal mobility, high demand of child labour in the homestead and the time needed for household chores. It should also consider rainy seasons, when pastoralist Dasanech children are required to be available in one place, movement patterns and climatic conditions, which will help to improve the relation of the school and sustain class attendance.

$>$ The district education offices and non-governmental and voluntary organizations should introduce non-formal mobile adult education programs as an alternative route to provide education for pastoralist Dasanech adults.

> Intra-tribal and inter-tribal conflicts have been found to be constraints to the educational participation of pastoral Dasanech children. Thus, this study recommends that the South Omo Zonal administration together with the regional state and NGOs should use and strengthen by law the existing traditional conflict resolution institutions, mechanisms, and intercommunity negotiation forums of Dasanech and other pastoralist community.

$>$ South Omo Zonal health department and other non-governmental and humanitarian organizations should facilitate the mobile health services. The problem of health is serious not only for the human but also for their livestock. Therefore, the mobile veterinary services should be facilitated by the regional agricultural and health bureau and non-governmental organizations.

\section{References}

Akaranga (1995). Kenya Report Document Prepared within the Framework of the Joint IIEP/IICBA/UNESCO Study on "Education for Nomads in Eastern Africa." Paris: UNESCO/International Institute for Educational Planning

Ayalew (1998)."Some Trends in Regional Disparities in Primary School Participation in Ethiopia". The Ethiopia Journal of Education .vol.II, No.l.

Bishop, G. (1994). Alternative strategies for education. London: Macmillan Education Ltd.

Bruns B. and Mingat A.(2003). Achieving Universal Primary Education by 2015: A Chance of Every Child. World Bank: Washington D.C.

Bruk Yemane.(2002)."Pastoralism and Agropastoralism: Past and Present".In the proceedings of the eighth annual Conference of Ethiopian Society of Animal production, 24-26 August 2002.Adiss Ababa.

Bugeke,J.C. (1995). "Nomadic Education in Tanzania." in Ezeomah (ed), "The Education of Nomadic Populations in Africa." Kaduna: UNESCO.

Burchardt (2000). "Preliminary Note on the Dakar Framework for Action." Focus on Adult and Non-formal Education. Addis Ababa.

Carr-Hill (2005). Education for Nomads in Eastern Africa. Paris: UNESCO/IIEP

COL. (2006). Reaching Nomadic Population in Africa; Common Wealth of learning [Online] Available: http.www.col.org.

Creswell, J .W(2007) Research Design, Qualitative-Quantitative and Mixed Approaches. London: Sage Publications. 
Dawit Abebe (2000). "Pastoralism and Agro-pastoralism: Past and Present." Paper presented in the Proceedings of the eighth Annual Conference of Ethiopian Society of Animal Production, August 24 - 26. Addis Ababa.

Doornbos, M. \& Markakis(2000)."State Policy and the Predicaments of Pastoralism in the Horn of Africa" in M. Doorabos(eds), Institutionalizing Development policies and Resource Strategies in Eastern Africa and India.London:Macmillan Press Ltd.

Dyer,C, \& Choksi, A. (1997). "Education is Like Wearing Glasses: Nomads' View of Literacy." International Journal of Education and Development. UK: Pergaman. Vol. 18, No.1

(1998). "Distance Education for Nomads."In Tahir (ed.), Reading on distance education for the pastoral nomads of Nigeria. Zaria: Ahmadu Universty press.

Ezeomah, C. (1998). Educating Nomads For Self Actualization and Development: Literacy Lessons. Switzerland: International Bureau of Education.

Fekade (1990)."Pastoral Nomadism and rural Development", In S.Pausewang (ed.), Ethiopia; Options for Rural Development. London: Zed Books Ltd.

Fekadu Gedamu (1984).The Nomadic areas of Ethiopia. UNDP: Addis Ababa.

Getachew Kassa (2001).Among the Pastoral Dasanech in Ethiopia: Tradition, continuality, and socioeconomic change. Netherlands: International Book

Helland,J.(2000)."Participation and Governance in the Development of Borenna".InSalih(ed.).African Pastoralism: Conflict, Institution and Good Governance. London: Pluto Press.

Heron, P.(1993)."Education for Nomads,"Nomadic people, Vol. 3, No.1

Hyde,K.A.(1989). Improving women's education in sub-Saharan Africa. Washington D.C: The World Bank.

--------(1995).Girls and schools in Sub-Saharan Africa: From Analysis to Action. Washington D.C: The World Bank.

ILCA(1981). Farmers and pastoralists. Tcheffa Valley Study. Contributing papers, No.2, ILCA Research Report.

Kratli, S. (2000).Education provision to Nomadic pastoralists: a review of the literature. Sussex: IDS.

Lawshe,C.H (1975). "A quantitative approach to content validity". Personnel Psychology, Vol,28, No.5.

Maglad, A.(1994).School Supply, Family Backgrounds and Gender Specific School Enrollment and Attainment in Sudan. Vol. 2, No.2.

MOE(2007).An Evaluation of Enabling Education Network. Addis Ababa: MoE

Mugerwa,K (1992).Range Land Tenure and Resource Management: Overview of pastoralism in Uganda. Kampala: Mekerer University.

Noriega, C. (1996). The Quality of primary education. IIEP: Mexico.

Nkinyangi (1981).Education for pastoralists: Development planning by trial and error.Ottawa: International Research center.

Markakis, J. (1993). Conflict and the decline of pastoralism in the Horn of Africa. London: Macmillan.

------(2000). The Bias Behind Nomadic Education. Sussex: IDS

Patton, M.Q.(1990).Qualitative evaluation and research methods. Newbury Park:Sage publications.

Ronde, S. (1980). "The Kawahla and Their Education." Paper for CESO Lecture Series of Education Problem in Developing countries: The Hague.

Rumberger, R.W. (1987). "High School Dropouts: A Review of Issues and Evidence." Review of Educational Research. Vol. 57, No.2.

Sifuna, D. (2005). "Increasing Access and Participation of pastoralist communities in Primary Education in Kenya". Review of education. Vol.5No.1.

Shebeshi \& Kidane(1997)."Nomadic education in Ethiopia", In Ezeomah(ed). The Education of Nomadic Population in Africa. Bredi: UNESCO.

SNNPR(2012). Education Annual Abstract, Southern Nation and Nationalities Regional State

Steven, D. (1993). Girls and basic education. DFID: University of Sussex.

Tahir.G.(2006). Setting the stage: Nomadic life and the implication for education provision. Abuja: Universal Education Commission.

Taylor, P.(1997). Contextualizing teaching and learning in rural primary schools. London: DFID.

UNESCO (1995).Development since Jomtien - EFA in the Middle East and North Africa. Paris: IIEP/UNESCO.

UNESCO/IIEP(2002). The education of nomadic population in Ethiopia. UNESCO/ICBA (2005).Improving the Participation of Disadvantaged Children in Primary Education. Paris: UNESCO.

UNICEF (2000).Mongolia Adolescents Need Assessment Survey Report. Ulaanbaatar; UNICEF.

Woldemichael Barhane (1995). Education for Pastoral Communities in Eritrea (A Research Study) Asmara.

World Bank(1988).Education in Sub-Saharan Africa: Policies for adjustment, revitalization, and expansion. Washington DC: World Bank.

World Bank(1995).Primary Education: Country Level Analysis. Washington D.C: World Bank. (1996). Priorities and strategies for education. Washington DC: World Bank..

(1998).Education in Sub-Saharan Africa: Policies for adjustment, revitalization, and expansion. Washington D.C: World Bank. (2003).Achieving universal primary education by 2015: a Chance of Every Child. Washington DC: World Bank.

$\overline{Y a c o b}$ Arsano (1995). "Development of land tenure Policies in Ethiopia with an Illustrative Case of the Ogaden" in Seyoum GebreSilassie (ed.), in Pastoral land Tenure System in the Horn of Africa: PENHA. 